\title{
MEMBANGUN KARAKTER KEBANGSAAN GENERASI MUDA BANGSA MELALUI INTEGRASI PENDIDIKAN FORMAL, INFORMAL DAN NONFORMAL
}

\author{
${ }^{1}$ Dinie Anggraeni Dewi \\ ${ }^{1}$ Program Studi PPKn \\ Fakultas Keguruan dan Ilmu Pendidikan \\ Universitas Islam Nusantara, Bandung \\ Email: anggraenidewidhinie@gmail.com
}

\begin{abstract}
The current state of corruption should encourage every citizens of the nation, all parties, the leaders of the nation, law enforcement officials, educators and religious leaders, to focus their attention to character building. Character development should be established as part of the national strategy to improve nation's life. The study begins from my concern about the backwardness of character education in Indonesia. The article concludes that to be successfull, character development should include the participation of three important institutions of social life: family (informal), school (formal) and community (nonformal) so as to create sustainability and harmonization.
\end{abstract}

Keywords: Character nation, Young Generation, Formal Education, Informal Education, Nonformal Education.

\begin{abstract}
ABSTRAK
Merajalelanya korupsi menandai bahwa persoalan pendidikan karakter bangsa harus menjadi perhatian semua pihak, pemimpin bangsa, aparat penegak hukum, pendidik dan tokoh-tokoh agama, golongan dan lain sebagainya. Pembangunan karakter harus dibentuk. Latar belakang penulisan, dari keprihatinan penulis tentang persoalan yang dihadapi bangsa Indonesia dalam hal pendidikan karakter bangsa. Dari hasil analisis dan pembahasan, didapatkan kesimpulan bahwa pembangunan karakter bangsa jika ingin efektif dan utuh mesti menyertakan tiga institusi, yaitu keluarga (informal), sekolah (formal) dan masyarakat (nonformal) sehingga tercipta kesinambungan dan harmonisasi.
\end{abstract}

Kata Kunci: Karakter Bangsa, Generasi Muda, Pendidikan Formal, Pendidikan Informal dan Pendidikan Nonformal.

\section{PENDAHULUAN}

Dalam dunia pendidikan, proses akultutasi dan perubahan perilaku bangsa menjadikan masyarakat memasuki complex adaptif system. Dalam keadaan seperti ini tampak perilaku masyarakat menjadi lebih buruk. Tidak mengherankan apabila era sekarang ini ditemukan berbagai karakter manusia Indonesia yang menampilkan sifat pembohong, manipulasi, korupi, serakah, kolusi, nepotisme, kerusuhan antar etnis, pembunuhan dan sederetan peristiwa lainnya. Suparno (Sukarjo, 2009) mengatakan bahwa pendidikan di Indonesia sekarang ini dapat diibaratkan seperti mobil tua yang mesinnya rewel yang sedang berada di tengah arus lalu lintas di jalan bebas hambatan. Pada suatu sisi pendidikan di Indonesia saat ini dirundung masalah besar yaitu mutu 
pendidikan yang masih rendah, sistem pembelajaran yang belum memadai dan krisis moral yang melanda masyarakat. Sedangkan pada sisi lain tantangan memasuki mileneum ketiga tidaklah main-main. Hari ke hari makin banyak tanpa ada titik terang penyelesaian.

Semua lini kehidupan mengalami persoalan dan cobaan yang tak habis-habisnya, bahkan semakin parah. Disamping itu, khususnya setelah kejatuhan Soeharto, Mei 1998, banyak terjadi peristiwa yang memiriskan budi kemanusiaan. Kita melihat bagaimana martabat kemanusiaan bangsa Indonesia sudah terpuruk ke jurang paling dalam, mendekati tingkat kebinatangan. Kekerasan demi kekerasan yang terjadi di Indonesia merupakan suatu indikasi bahwa masyarakat kita sudah terkondisi dalam budaya tanpa hukum. Semua ini mengindikasikan, kekerasan telah diterima oleh sebagian masyarakat kita sebagai suatu kebiasaan, yang bukan kejahatan, tetapi dijadikan santapan sehari-hari dalam menghadapi persoalan-persoalan hidup.

Sekolah-sekolah memang melahirkan manusia cerdas, namun kurang memiliki kesadaran akan pentingnya nilai-nilai moral dan sopan santun dalam hidup bermasyarakat. Ini tampak dalam kasus tawuran antarsekolah, antarfakultas, antarperguruan tinggi dan tindakan kekerasan yang hidup di dunia pendidikan formal. Lulusan perguruan tinggi yang mulai bekerja, tergiur berbuat tidak jujur karena tidak punya pegangan kebajikan. Sebagian mahasiswa kita merasa bangga jika kuliah tidak ada dosennya, perpustakaan banyak kosong, internet digunakan untuk hal-hal yang tidak terpuji, alergi buku yang berbahasa asing, suka meniru skripsi orang lain alias plagiator. Perilaku tawuran atau kekerasan atau perilaku tidak terpuji lainnya di sekolah-sekolah atau kampus-kampus, tidak mungkin terjadi dengan tiba-tiba. Seseorang menampilkan perilaku itu merupakan hasil belajar juga, baik secara langsung maupun tidak langsung.

Dalam dunia pendidikan kita sekarang ini, tidak boleh lagi terjadi proses pendidikan yang lebih mendahulukan dimensi kognitif, sehingga dimensi humaniora dilalaikan, atau dengan kata lain, prestasi akademik diutamakan, pembinaan manusia sebagai pribadi dilalaikan. Predikat bangsa Indonesia yang ramah dan sopan menjadi kehilangan makna, manakala pembangunan karakter bangsa menjadi kabur dilanda isu kekerasan dan korupsi (Situmorang,2010).

Pembentukan karakter terutama peserta didik menjadi hal yang urgen dan mendesak untuk segera direalisasikan dalam rangka mewujudkan masyarakat yang lebih baik, yaitu masyarakat yang dapat menghadapi tantangan regional dan global. Tantangan regional dan global yang dimaksud adalah bagaimana generasi muda kita tidak sekedar memiliki kemampuan akademis yang menitik beratkan pada kemampuan kognitif saja, tetapi aspek afektif dan moralitas juga tersentuh. Di sisi lain nilai-nilai dan semangat berbangsa dan bernegara dapat menjadi inspirasi bagi penguatan identitas pendidikan karakter bangsa dalam menghadapi krisis multidimensi. Pendidikan sebagai totalitas usaha dan tindakan harus dijalankan melalui tiga lembaga pendidikan yaitu, keluarga, 
sekolah dan masyarakat. Oleh karena itu, diperlukan integrasi lembaga pendidikan keluarga, pendidikan sekolah dan lembaga pendidikan masyarakat dalam menyelenggarakan pendidikan karakter. Penguatan ketiga lembaga pendidikan tersebut menunjukkan bahwa pendidikan karakter sangat diperlukan dalam rangka mengantisipasi persoalan-persoalan dimasa depan yang semakin kompleks.

\section{METODE PENULISAN}

Tulisan ini menggunakan studi literatur sebagai pendekatan penelitiannya. Mengelaborasi secara sistematis dari berbagai konsep tentang pendidikan karakter yang bersumber dari jurnal, buku dan penelitian guna mengkonstruksi tentang wacana karakter kebangsaan generasi muda melalui integrasi pendidikan formal, informal dan nonformal.

\section{PEMBAHASAN}

Pembangunan karakter bangsa sebenarnya sudah sejak lama diucapkan oleh Bung Karno (1961) yaitu dedication of life kepada para olahragawan dan pembina olah raga, agar dapat melaksanakan Amanat Penderitaan Rakyat sesuai kerangka segi-segi cita-cita bangsa yang termasuk dalam Nation and Character Building Indonesia. Ungkapan ini meninggalkan bekas yang mendalam di hati kita semua. Ungkapan ini menghidupkan harapan besar dalam hati kita bersama. Bung Karno juga mengatakan Bangsa ini harus dibangun dengan mendahulukan pembangunan karakter (character building), karena character building inilah yang akan membuat Indonesia menjadi bangsa yang besar, maju, dan jaya serta bermartabat. Kalau hal ini tidak dilakukan, maka bangsa ini menjadi bangsa kuli (Abidinsyah, 2011)

Ketika Bung Karno mengucapkan kata-kata ini, rasanya diucapkan dalam konteks politik. Jadi yang dimaksud ialah watak bangsa harus dibangun. Tetapi, ketika kata-kata ini diungkapkan oleh para pendidik, dari Ki Hajar Dewantara, hingga Mohammad Said, konteksnya adalah pendidikan. Yang dimaksudkan ialah pendidikan watak untuk siswa. Bagaimana cara mendidik anak di sekolah agar selain menjadi pinter juga menjadi manusia berwatak. Sementara, White (Hidayatullah, 2010), menyatakan bahwa pembangunan karakter adalah usaha paling penting yang pernah diberikan kepada manusia. Pembangunan karakter adalah tujuan luar biasa dari sistem pendidikan yang benar. Hasil studi Marvin Berkowitz (Hawadi, 2008) para siswa yang berasal dari sekolah dengan menerapkan pendidikan berkarakter menunjukkan peningkatan motivasi dalam meraih prestasi akademik. Tidak hanya itu, kelas-kelas yang secara komprehensif terlibat dalam pendidikan karakter, menunjukkan penurunan drastis pada perilaku negatif siswa yang menghambat keberhasilan akademik. Williams (Hawadi, 2008), menambahkan bahwa dengan pendidikan karakter, seorang anak akan lebih cerdas secara emosi.

Williams menjelaskan bahwa terdapat kecenderungan bahwa anakanak yang memiliki masalah dengan kecerdasan emosi akan mengalami kesulitan belajar, bergaul, dan mengontrol emosinya. Sebaliknya, anak-anak dan para remaja yang berkarakter atau memiliki kecerdasan emosi yang tinggi, cenderung 
terhindar dari masalah-masalah yang biasanya dihadapi remaja, seperti kenakalan remaja, tawuran, perilaku seks bebas, penyalahgunaan obatobatan terlarang, dan lain sebagainya. Sehingga, dengan demikian kecerdasan emosi ini merupakan salah satu bekal penting dalam mempersiapkan anak menyongsong masa depan karena dengannya seseorang akan dapat berhasil dalam menghadapi tantangan, termasuk tantangan untuk berhasil secara akademis.

Dari temuan penelitian di atas, kini kita harus menyatakan bahwa institusi pendidikan, baik rumah, sekolah, maupun masyarakat tempat penting dan strategis dalam membangun karakter bangsa. Oleh karena itu, diperlukan keterpaduan lembaga pendidikan keluarga, pendidikan sekolah dan lembaga pendidikan masyarakat dalam menyelenggarakan pendidikan karakter bangsa.

\section{Pendidikan Keluarga (Informal)}

Pendidikan karakter dimulai dari lingkungan keluarga. Pendidikan yang diberikan dalam lingkungan keluarga yang mempersiapkan suatu model mendidik untuk membentuk kecakapan hidup sebagai dasar dalam kehidupan selanjutnya. Apabila pendidikan kecakapan hidup sudah tertanam pada pendidikan keluarga maka tidak sulit untuk mengembangkannya di lingkuan sekolah. Karakter yang ditampilkan oleh peserta didik dalam kehidupan sosialnya dipengaruhi oleh lingkungan keluarga dan di luar keluarga. Peranan keluarga sebagai lingkungan sosial pertama, memiliki hubungan dengan kepribadian anak. Keluarga sebagai pintu pertama dan utama yang dilalui individu merupakan sarana awal dan pokok dalam membentuk kepribadian dan karakter. Di dalam keluarga seseorang dapat hidup bersama dengan sekelompok orang secara akrab. Karena salah satu fungsi keluarga adalah merawat, melatih anak, menjaga dan mendidik anakanak secara mental spritual. Pendidikan karakter dan nilai-nilai keperibadian menjadi tujuan utama pendidikan kaluarga.

Pendidikan keluarga

diposisikan sebagai lembaga pembentukan kecerdasan spiritual. Dalam keluarga benih pendidikan mulai tumbuh dalam hubungan cinta kasih, tolong menolong, dan saling memberi pengertian. Keluarga merupakan lembaga pendidikan permulaan sehingga orang tua (ayah dan ibu) pertama kalinya berstatus sebagai panutan (guru) untuk memberikan pendidikan budi pekerti, nilai kebaikan dan nilai etika. Pada dasarnya keluarga berkewajiban meletakkan dasar kependidikan berupa potensi nilai kemanusiaan. Potensi kecerdasan spiritual menjadi tumbuh dan berkembang apabila dirawat dan dijabarkan dalam kehidupan sehari-hari oleh keluarga (orang tua).

Tiga moral spiritual yang dikembangkan dalam keluarga adalah syukur, sabar dan ikhlas sebagai benteng dalam upaya membangun kecerdasan spiritual dalam rangka menanamkan nilainilai moral kepada anak (Suhartono, 2009:67). Orang tua sebagai pemeran utama pendidikan keluarga harus mampu menanamkan kepada anakanaknya watak rendah hati dan kejujuran. Bukan menanamkan watak sombong, angkuh. Spirit bersabar harus pula ditanamkan dalam pendidikan keluarga. Apabila watak kesabaran telah tertanam 
dengan baik dalam kehidupan keluarga, maka akan terhindar dari perbuatan memaksakan kehendak untuk mendapatkan sesuatu yang diinginkan, seperti korupsi. Selain spirit syukur dan sabar, keluarga dituntut pula untuk mengembangkan spirit ikhlas dalam proses pendidikan anak dalam keluarga.

Keikhlasan mencerminkan adanya kesadaran bahwa seluruh kegiatan kehidupan pada akhirnya bergerak menuju tujuan akhir yaitu kembali keasal mulanya. Dengan demikian dapat dipahami bahwa keluarga sebagai sistem sosial merupakan faktor determinan pertama dan utama dalam memberikan pendidikan kepribadian, budi pekerti, dan karakter dalam rangka pembentukan pondasi watak terutama pada anak berumur di bawah lima tahun, sehingga di atas pondasi itulah sifat-sifat kepribadaian anak yang diperolehnya melalui proses inkulturasi dan sosialisasi di lingkungan keluarga sangat menentukan pula terhadap pembentukan dan perkembangan kecerdasan moral emosional anak.

Keluarga sebagai lingkungan pembentukan watak dan pendidikan pertama dan utama mestilah diberdayakan kembali. Sebagaimana disarankan Phillips (2000), keluarga hendaklah kembali menjadi school of love, sekolah untuk kasih sayang. Sementara Azra (2008) menyatakan, dalam perspektif Islam, keluarga sebagai madrasah mawaddah wa rahmah, tempat belajar yang penuh cinta sejati dan kasih sayang. Berdasarkan sebuah hadits yang diriwayatkan Anas r.a (Azra 2008), keluarga yang baik memiliki empat ciri, yaitu: memiliki semangat (gairah) dan kecintaan untuk mempelajari dan menghayati ajaran- ajaran agama dengan sebaik-baiknya untuk kemudian mengamalkan dan mengaktualisasikannya dalam kehidupan sehari-hari; setiap anggotanya saling menghormati dan menyayangi, saling asah dan asuh; dari segi nafkah (konsumsi) tidak berlebih-lebihan, tidak ngoyo atau tidak serakah dalam usaha mendapatkan nafkah, sederhana atau tidak konsumtif; serta selalu berusaha meningkatkan ilmu dan pengetahuan setiap anggota keluarganya melalui proses belajar dan pendidikan seumur hidup (life long learning), minal-mahdi ila allahdi. Contoh: mampu membedakan mana yang benar dan yang salah, yang baik dan yang buruk, yang dilarang dan yang diperintah. Bermasyarakat (13 tahun >). Anak diajarkan memiliki integritas, dan kemampuan adaptasi. Keteladanan (contoh) merupakan metode efektif untuk membangun karakter anak di dalam keluarga. Dalam hal ini, keteladanan tentunya dari semua pihak, mulai ayah, ibu, dan di antara anak-anak. Dengan keteladanan ini, anak-anak di dalam keluarga dapat mencontoh sikap-sikap positif, seperti disiplin, bertanggung jawab, berani, saling menghormati, jujur, dan sikap-sikap lainnya.

\section{Pendidikan Sekolah (Formal)}

Pendidikan

sekolah

merupakan lembaga pendidikan kedua setelah pendidikan keluarga. Pendidikan sekolah dituntut untuk mampu mengembangkan berbagai potensi yang dibawa peserta didik dari pendidikan keluarga. Lembaga pendidikan sekolah bertanggung jawab atas kepercayaan keluarga atau masyarakat dalam hal pembinaan potensi akademik (inteltual) anak. Selain itu pendidikan sekolah diharapkan 
mampu mempersiapkan peserta didik untuk memiliki kemampuan dalam menjaga dan mengembangkan terbentuknya kreativitas (Kecerdasan intelektual) dan sikap (kecerdasan moral) sebagai bagian dari pencerdasan moral emosional.

Pendidikan bukan hanya sebatas transfer of knowledge, melainkan sebagai upaya pembimbingan peserta didik untuk mencapai perkembangan, baik secara jasmani maupun rohani ke arah kedewasaan. Secara lebih luas, pendidikan juga mencakup usahausaha untuk membangun watak, sikap, dan kepribadian peserta didik agar menjadi manusia sempurna (insan kamil). Seperti dikemukakan Fraenkel (1977), sekolah tidaklah semata-mata tempat di mana guru menyampaikan pengetahuan melalui berbagai mata pelajaran. Sekolah juga adalah lembaga yang mengusahakan usaha dan proses pembelajaran yang berorientasi pada nilai (valueoriented enterprise). Guru dituntut memiliki kompetensi tertentu, yakni: kompetensi profesional, pedagogis, personal dan sosial. Dari empat aspek tersebut, aspek yang paling mendasar untuk menjadi seorang guru yang mampu mendidik karakter siswa, yaitu aspek kepribadian (personalitas), karena aspek inilah yang menjadi cikal bakal lahirnya komitmen diri, dedikasi, kepedulian dan kemauan kuat untuk terus berbuat yang terbaik dalam kiprahnya di dunia pendidikan (Nurchaili, 2010).

Menurut Martadi (2010), untuk pembentukan watak melalui sekolah dapat dilakukan pembangunan budaya sekolah dengan menciptakan suasana sekolah yang mencerminkan karakter. Implementasinya, kegiatan intra dan kokurikuler secara terintegrasi pada semua mata pelajaran. Ekstrakurikuler melalui berbagai kegiatan antara lain: KIR, Pramuka, kesenian, olah raga, dokter kecil, PMR. Model pengembangan esensi nilai karakter di sekolah yang dapat dieksplor, diklarifikasi dan direalisasikan melalui pembelajaran intra dan ekstrakurikuler dapat dilihat pada tabel berikut :

\begin{tabular}{|l|l|l|}
\hline \multicolumn{1}{|c|}{ Ideology } & \multicolumn{1}{|c|}{ Religion } & \multicolumn{1}{c|}{ Culture } \\
\hline - Discipline, law and & - Belief in god the & - Tolerance and \\
almighty & goodwill \\
- Love country & - Devotion to god & - Kindness \\
- Democratic & - Love religion & - Empathy \\
- Altruistic & - Adherence to & - Manner and etiquette \\
- Courageous & religious teaching & - Politiness \\
- Solidarity & - Righteous & - Cheerfulness \\
- Nationalistic & - Benevolent & - Healthy \\
- Patriotic & - Helpfulness & - Wealthy \\
- Productive citizen & - Hope and truthfulness & - Friendship \\
- Enlightened & - Sense of humanism & - Acknowledgement \\
- National pride & - Humanism & - Respect \\
- National loyalty & - Justice & - Gratitude. \\
& - Moral and spiritual & \\
\hline
\end{tabular}


Untuk pembentukan karakter melalui pendidikan di sekolah, Azra (2008) mengusulkan ada 3 (tiga) langkah sebagai berikut: Menerapkan pendekatan modelling atau exemplary atau uswah hasanah, yakni mensosialisasikan dan membiasakan lingkungan sekolah untuk menghidupkan dan menegakkan nilai-nilai akhlak dan moral yang benar melalui model atau teladan. Setiap guru dan tenaga kependidikan di lingkungan sekolah hendaknya mampu menjadi uswah hasanah yang hidup bagi setiap peserta didik. Mereka juga harus terbuka dan siap untuk mendiskusikan dengan peserta didik tentang berbagai nilai-nilai yang baik tersebut. Menjelaskan atau mengklarifikasi kepada peserta didik secara terus menerus tentang berbagai nilai yang baik dan yang buruk. Usaha ini bisa dibarengi pula dengan langkah-langkah memberi penghargaan nilai-nilai yang baik dan sebaliknya mengecam dan mencegah berlakunya nilai-nilai yang buruk..

Dalam proses pendidikan karakter, pendidikan harus melalui aspek kognitif, afektif, dan psikomotorik (Lickona, 1991). Dengan demikian, sekolah harus membantu siswa untuk memahami nilai-nilai utama, mengadopsinya, dan menerapkannya dalam keseharian. Banyak cara yang dapat dilakukan dalam upaya penanaman nilai pada siswa, salah satunya lewat buku cerita rakyat. Media ini bisa jadi menyenangkan bagi anak-anak sehingga besar kemungkinan, nilainilai yang dikandung cerita tersebut dapat diserap dengan baik. Melalui kajian tematik dan amanat terhadap teks tersebut diharapkan akan ditemukan beberapa aspek pragmatik yang dapat dimanfaatkan sebagai kerangka acuan dalam mendidik anak-anak bangsa sebagai generasi penerus sehingga masyarakat Indonesia dapat menemukan kembali jati dirinya (Karyanto et.al, 2008).

Lickona (1991) menyebutkan sedikitnya terdapat 6 (enam) hal yang menjadi sasaran untuk dilakukan siswa sebagai indikator bahwa pendidikan karakter positif pada ranah kognitif dapat terpenuhi: 1) Sadar atas nilai-nilai moral yang ada, 2) Memahami hal-hal yang dibutuhkan untuk menerapkan nilainilai moral pada kondisi nyata, 3) Mengambil perspektif, dalam artian tidak hanya mengedepankan dirinya dalam memandang suatu permasalahan, tetapi juga berupaya melihat suatu hal berdasarkan sudut pandang orang lain, 4) Melakukan penalaran moral, 5) Berpikir dalam rangka mengambil keputusan, 6) Memiliki pengetahuan moral. Dari hal tersebut di atas, hal yang perlu dipahami adalah seseorang mungkin saja secara pemahaman telah amat mengerti mengenai hal-hal yang benar dan hal yang salah. Namun pada kenyataannya, masih saja ada di antara orang dengan pemahaman tersebut yang tetap memilih hal yang salah. Dengan pendidikan nilai-nilai di sekolah, pembangunan karakter yang kuat dapat dirintis secara berkelanjutan. Untuk keberhasilan ini masih diperlukan tiga unsur penting lain : membangun kultur sekolah yang mampu membangun karakter siswa, kepemimpinan yang berkarakter dan menjunjung tinggi kebenaran yang hakiki.

\section{Pendidikan (nonformal) \\ Masyarakat} Lingkungan masyarakat luas jelas memiliki pengaruh besar terhadap keberhasilan pembentukan 
karakter. Dari perspektif Islam, menurut Shihab (1996), situasi kemasyarakatan dengan sistem nilai yang dianutnya, mempengaruhi sikap dan cara pandang masyarakat secara keseluruhan. Misalnya, penganut paham materialistis memandang bahwa nilai yang tertinggi adalah material, sedangkan di kalangan masyarakat hedonis berpandangan bahwa nilai yang tertinggi adalah nilai kenikmatan. Jika sistem nilai dan pandangan masyarakat terbatas pada kini dan di sini, maka upaya dan ambisinya terbatas pada kini dan di sini pula. Dalam konteks ini, Azra (2008) menyebutkan bahwa dalam Al-Qur'an banyak ayatnya menekankan tentang pentingnya kebersamaan, tujuan bersama, gerak langkah bersama, solidaritas yang sama. Setiap agama selalu mengajarkan kebaikan kepada umatnya, sikap saling menghormati, bersikap jujur, santun, disiplin, dan lain sebagainya. Oleh karena, internalisasi ajaran-ajaran agama dalam kehidupan sehari-hari akan memantapkan karakter seseorang baik dalam kapasitasnya sebagai individu maupun sebagai warga bangsa Indonesia.

Melalui agama, individu menciptakan hubungan yang privat dengan Tuhan. Melalui agama pula, seseorang dapat berinteraksi secara baik dengan orang lainnya, dan melalui agama pula, seseorang dapat menebarkan kebaikan dan menguatkan karakter pribadinya. Tak berlebihan dikatakan, kalau kita mau berhasil membentuk karakter bangsa di tengah-tengah masyarakat, maka harus ada seorang pemimpin yang berkarakter, seperti disiplin, bertanggung jawab, berani, saling menghormati, jujur, dan sikap-sikap lainnya. Jadi pemimpin di masyarakat harus menjadi teladan. Dengan keteladanan ini, merupakan langkah pembimbingan masyarakat dalam rangka membangun karakter bangsa. Pendidikan karakter bangsa di lingkungan masyarakat harus dimaknai sebagai gambaran perilaku warga masyarakat dalam kesehariannya. Artinya seluruh lini dan komponen di lingkungan masyarakat hendaknya mencerminkan terwujudnya pendidikan karakter itu sendiri. Baik dalam bentuk materi maupun aplikasi di kehidupan mereka. Pengembangan pendidikan karakter di lembaga pendidikan masyarakat seperti pendidikan keagamaan, juga berhubungan dengan pengembangan akhalq, moral dan pengembangan agama serta nilai spiritualitas seseorang.

Pembangunan karakter jika ingin efektif dan utuh mesti menyertakan tiga institusi, yaitu keluarga, sekolah dan masyarakat. Hal ini sejalan dengan pandangan Phillips (2000), bahwa pendidikan karakter haruslah melibatkan semua pihak, yaitu keluarga, sekolah dan masyarakat. Karena itu, langkah pertama yang harus dilakukan adalah menyambung kembali hubungan dan educational networks yang nyaris putus antara ketiga institusi pendidikan ini. Tanpa tiga institusi itu, program pendidikan karakter sekolah hanya menjadi wacana semata. Dengan kata lain, pembangunan karakter tidak akan berhasil selama ketiga institusi pendidikan tidak ada kesinambungan dan harmonisasi. Proses pembudayaan dan pemberdyaan dari integrasi pendidikan formal, informal dan nonformal adalah sebagai berikut: 


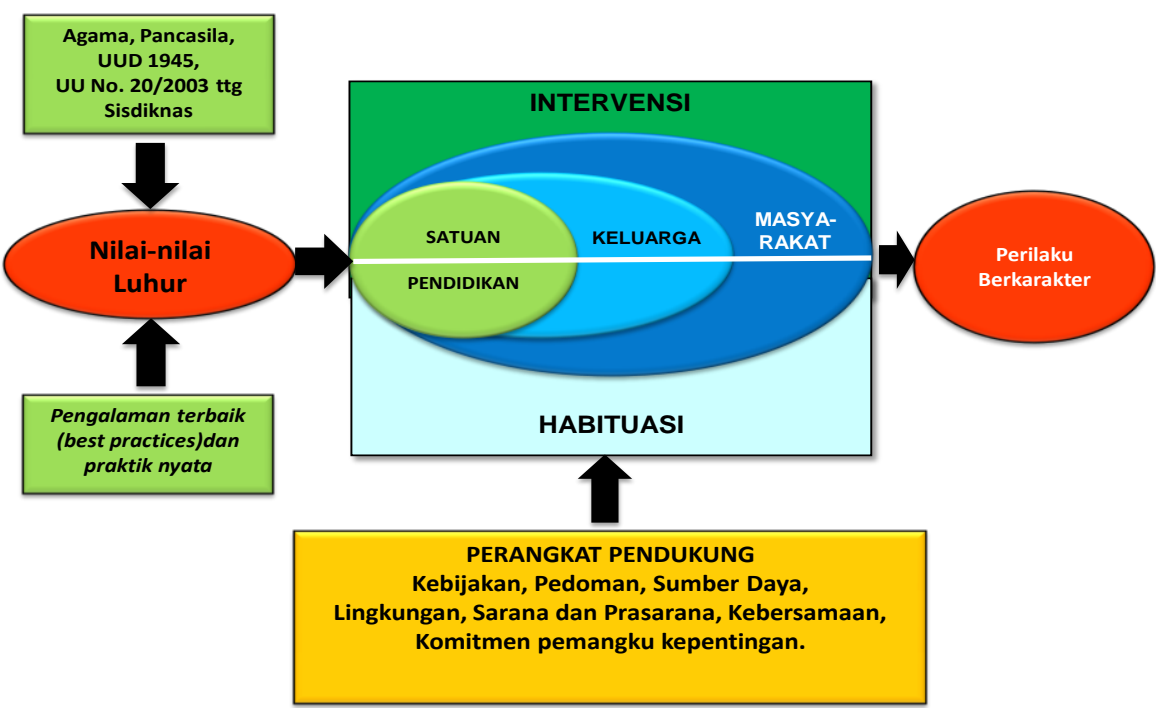

Sumber : Kementrian Koordinator Kesejahteraan Rakyat Republik Indonesia (2010)

Pada tataran mikro, pendidikan karakter ditata sebagai berikut :

1. Secara mikro pengembangan nilai/karakter dapat dibagi dalam empat pilar, yakni kegiatan belajar mengajar di kelas, kegiatan keseharian dalam bentuk udaya satuan pendidikan (school culture); kegiatan ko-kurikuler dan/atau ekstra kulikuler, serta kegiatan keseharian di rumah, dan dalam masyarakat.

2. Dalam kegiatan belajar mengajar di kelas pengembangan nilai/karakter dilaksanakan dengan menggunakan pendekatan terintegrasi dalam semua mata pelajaran (embedded approach).

3. Dalam lingkungan satuan pendidikan dikondisikan agar lingkungan fisik dan sosio cultural satuan pendidikan memungkinkan para peserta didik bersama dengan warga satuan pendidikan lainnya terbiasa membangun kegiatan keseharian di satuan pendidikan yang mencerminkan perwujudan nilai/karakter.

4. Dalam kegiatan ko-kurikuler, yakni kegiatan belajar di luar kelas yang terkait langsung pada suatu materi dari suatu mata pelajaran, atau kegiatan ekstrakulikuer yakni kegiatan satuan penddidikan yang bersifat umum dan tidak terkait langsung pada satu mata pelajaran, seperti kegiatan dokter kecil, Palang Merah Remaja, Pecinta Alam dll, perlu dikembangkan proses pembiasaan dan penguatan (reinforcement) dalam rangka pengembangan nilai/karakter

5. Di lingkungan keluarga dan masyarakat diupayakan agar terjadi proses penguatan dari orang tua/wali serta tokoh-tokoh masyarakat terhadap perilaku 
Secara diagramatik, pendidikan karakter pada tatanan mikro tersebut digambarkan sebagai berikut :

\section{STRATEGI MIKRO PENDIDIKAN KARAKTER}

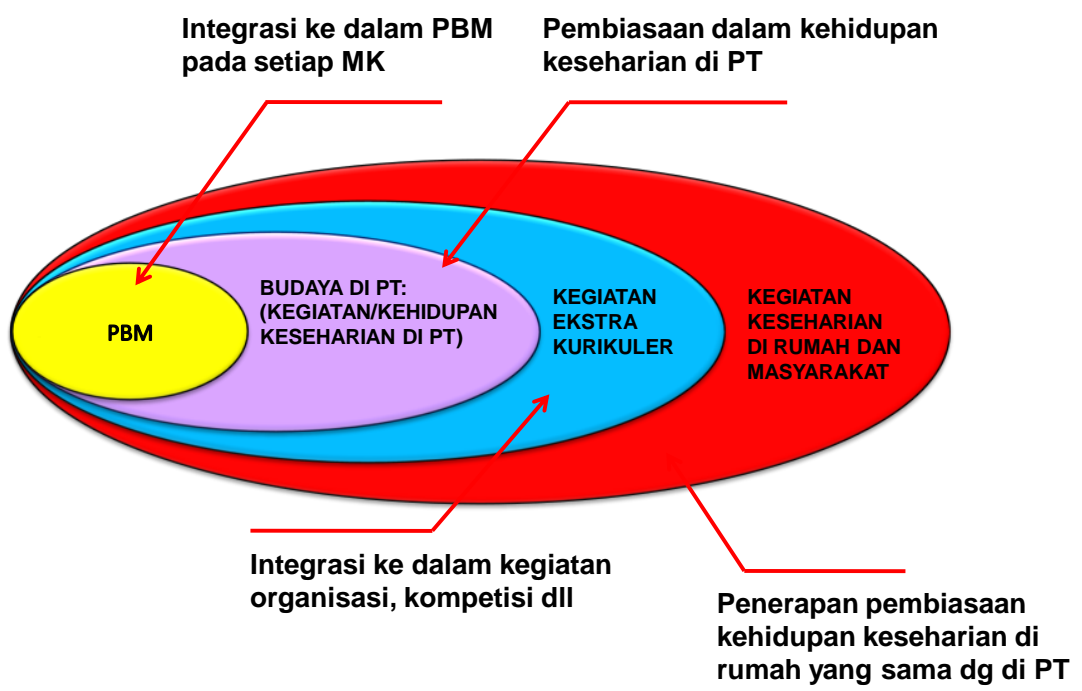

Sumber : Kementrian Koordinator Kesejahteraan Rakyat Republik Indonesia (2010)

Integrasi antara pendidikan formal, informal dan nonformal untuk membangun karakter bangsa dapat dilakukan dengan adanya kerjasama, sinergi dan komitmen antara masyarakat, keluarga dan sekolah. Contoh : Menjalin kerja sama dengan orang tua peserta didik supaya nilai karakter bangsa juga ditanamkan di rumah, menjalin kerja sama dengan stakeholder di masyarakat supaya sekolah mampu lebih berkembang dan mampu meningkatkan mutunya, menjalin kerja sama dengan komite sekolah dan dewan pendidikan dalam rangka menghadapi tantangan global.

\section{SIMPULAN}

Upaya pembentukan karakter bangsa yang tercermin pada karakter individu warga masyarakat sangat ditentukan oleh kualitas proses pendidikan keluarga, sekolah dan masyarakat. Dalam keluarga pengembangan kecerdasan emosional ditentukan oleh kualitas pendidikan orang tua. Kualitas pendidikan orang tua bukan hanya dilihat dari tinggi rendahnya pendidikan formal, akan tetapi dilihat dari aspek perilaku dalam kehidupan sehari-hari, kesadaran akan kehidupan tumbuh dalam diri dan sifat objektif yang kuat sebagai pedoman hidup dalam keluarga. Selanjutnya, lembaga pendidikan sekolah bertanggung jawab pula 
untuk membangun kecerdasan emosional dalam mengembangkan karakter peserta didik. Selain pendidikan keluarga dan sekolah, tidak kalah penting dalam hal tanggung jawab terhadap pencerdasan moral emosional anak adalah masyarakat. Menurut eksistensinya, masyarakat adalah keseluruhan dari entitas sosial. Dari struktur eksistensi masyarakat seperti itu tampak peranan masyarakat dalam pencerdasan emosional atau bahkan dikatakan bahwa masyarakat adalah "bengkel" pencerdasan emosional dalam membentuk karakter anak dan warga masyarakat pada umumnya. Oleh karena itu, diperlukan integrasi antara pendidikan formal, informal dan nonformal untuk membangun karakter kebangsaan generasi muda bangsa. Dengan kata lain, pembangunan karakter tidak akan berhasil selama ketiga institusi pendidikan tidak ada kesinambungan dan harmonisasi.

\section{DAFTAR PUSTAKA}

Abidinsyah. (2011). Urgensi Pendidikan Karakter dalam Membangun Peradaban Bangsa yang Bermartabat, dalam Jurnal Socioscientia, 11(3); 11-21.

Azra, A. (2008). Pembangunan Karakter Bangsa: Pendekatan Budaya, Pendidikan dan Agama. Jakarta: Forum Kajian Antropologi Indonesia

Budimansyah, Dasim, dkk. (2011). Pendidikan Karakter : Nilai Inti Bagi Upaya Pembinaan Kepribadian Bangsa. Bandung : Widya Aksara Press.

Daniel Goleman. (1999). Emotional Intellegence, Terjemahan:
T. Hermaya. Jakarta: Gramedia Pustaka Utama.

Fagerlind, Ingemar and Lawrence J. Saha. (1983). Education and National Development: A Comparative Perspective. Oxford: Pergamon Press.

Fraenkel, J.R. (1977). How to Teach about Values : An Analytical Approach. New Jersey: Prentice Hall.

Hidayatullah, Furqon. (2010). Pendidikan Karakter Membangun Peradaban Bangsa. Surakarta: Yuma Pustaka.

Karyanto, P., dkk. (2008). Pembentukan Karakter Anak Menurut Teks Cerita Rakyat 'Ranggana Putra Demang Balaraja': Kajian Pragmatik Sastra, Dalam Jurnal Penelitian Din.Sos. 7(1): 45-53.

Kemdiknas. (2010). Bahan Pelatihan Penguatan Metodologi Pembelajaran Berdasarkan Nilai-nilai Budaya untuk membentuk Daya Saing dan Karakter Bangsa. Jakarta: Kemendiknas.

Kurniawan, Syamsul. (2014).

Pendidikan Karakter:

Konsepsi \&

Implementasnya secara Terpadu di Lingkungan Keluarga, Sekolah, Perguruan Tinggi dan Masyarakat. Yogyakarta: Arruzz Media.

Kusoema, Doni. (2010). Pendidikan Karakter: Strategi Mendidik Anak di Zaman Global. Jakarta: Grasindo.

Lawrence E. Saphiro. (1998). Mengajarkan Emosional Intelligence Pada Anak, 
Jakarta: Gramedia Pustaka Utama.

Lickona, T. (1991). Educating for Character: How Our Schools Can Teach Respect and Responsibility. New York: Bantam Books. -. (2012). Mendidik untuk Membentuk Karakter. Jakarta: Bumi Aksara. . Marvin W. Berkowitz \& Melinda C Bier. (2005). What Works In Character Education: A ResearchDriven Guide for Educators. Washington DC: Character Education Partnership.

Megawangi, Ratna. (2004).

Pendidikan Karakter; Solusi yang Tepat untuk Membangun Bangsa. Bogor: Indonesia Heritage Foundation.

Munir, Abdullah. (2011). Pendidikan

Karakter: Membangun

Karakter dari Rumah. Yogyakarta: Gava Media.

Muslich, Masnur. (2011). Pendidikan Karakter: Menjawab Tantangan Krisis Multidimensional. Jakarta: Bumi Aksara

Natasya, Harun. (2012). Revitalisasi Lembaga Pendidikan dalam Upaya Membangun Karakter Bangsa, dalam Jurnal Pemikiran Islam; 37 (1); 34-44.

Nurchaili. (2010). Membentuk Karakter Siswa Melalui Keteladanan Guru. Dalam Jurnal pendidikan dan kebudayaan. 16(3) ; 10-22.

Samani, Hariyanto. (2012). Konsep dan Model Pendidikan Karakter. Bandung: PT Remaja Rosdakarya.
Situmorang, H. (2010). Pembangunan Karakter Bangsa. Jurnal Pendidikan Penabur. 9(14) ; 25-34.

Winataputra, Udin. (2010) Implementasi Kebijakan Nasional Pembangunan Karakter Bangsa Melalui Pendidikan Karakter. Jakarta: Universitas Terbuka.

Zubaedi. (2011). Desain Pendidikan Karakter. Jakarta: Kencana Prenada Media. 